\title{
High levels of tissue inhibitor of metalloproteinase-1 (TIMP-1) in the serum are associated with poor prognosis in HPV-negative squamous cell oropharyngeal cancer
}

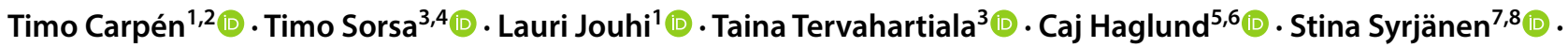

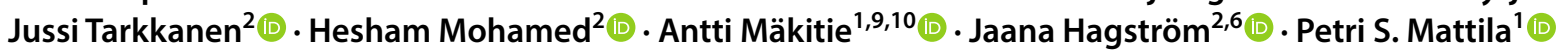

Received: 31 October 2018 / Accepted: 17 June 2019 / Published online: 25 June 2019

(c) The Author(s) 2019

\begin{abstract}
Background An emerging subset of oropharyngeal squamous cell carcinomas (OPSCC) is caused by HPV. HPV-positive OPSCC has a better prognosis than HPV-negative OPSCC, but other prognostic markers for these two different diseases are scarce. Our aim was to evaluate serum levels and tumor expression of matrix metalloproteinase-8 (MMP-8) and tissue inhibitor of metalloproteinase-1 (TIMP-1) and to assess their prognostic role in HPV-positive and HPV-negative OPSCC. Materials and methods A total of 90 consecutive OPSCC patients diagnosed and treated with curative intent at the Helsinki University Hospital between 2012 and 2016 were included. Serum samples were prospectively collected. An immunofluorometric assay and an enzyme-linked immunosorbent assay were used to determine MMP-8 and TIMP-1 serum concentrations, respectively. HPV status of the tumors was determined using a combination of HPV-DNA genotyping and p16-INK4a immunohistochemistry. The endpoints were overall survival (OS) and disease-free survival (DFS).

Results High TIMP-1 serum levels were strongly and independently associated with poorer OS (adjusted HR 14.7, 95\% CI $1.8-117.4, p=0.011$ ) and DFS (adjusted HR 8.7, 95\% CI 1.3-57.1, $p=0.024$ ) among HPV-negative patients; this association was not observed in HPV-positive OPSCC. Although TIMP-1 was immunoexpressed in the majority of the tumor tissue samples, the level of immunoexpression was not associated with prognosis, nor did MMP-8 serum levels.

Conclusion Our results indicate that serum TIMP-1 levels may serve as an independent prognostic marker for HPV-negative OPSCC patients.
\end{abstract}

Keywords HPV · Oropharyngeal cancer · MMP-8 · TIMP-1 · Survival · Prognosis

$\begin{array}{ll}\text { Abbreviations } \\ \text { CD } & \text { Cluster of differentiation } \\ \text { CI } & \text { Confidence interval } \\ \text { DFS } & \text { Disease-free survival } \\ \text { FAK } & \text { Focal adhesion kinase } \\ \text { HR } & \text { Hazard ratio } \\ \text { IHC } & \text { Immunohistochemistry } \\ \text { MMP-8 } & \text { Matrix metalloproteinase-8 } \\ \text { MMPs } & \text { Matrix metalloproteinases }\end{array}$

Part of this study has been presented as an abstract at the 6th World Congress of the International Federation of Head and Neck Oncologic Societies (IFHNOS) on September 1st-4th in 2018 in Buenos Aires, Argentina.

Timo Carpén

timo.carpen@fimnet.fi

Extended author information available on the last page of the article
OPSCC Oropharyngeal squamous cell carcinoma

OS Overall survival

SD Standard deviation

TIMP-1 Tissue inhibitor of metalloproteinase-1

TIMPs Tissue inhibitors of metalloproteinases

TMA Tissue microarray

\section{Introduction}

The incidence of oropharyngeal squamous cell carcinoma (OPSCC) is increasing in many countries due to infection with oncogenic HPV strains. Currently, more than a half of all newly diagnosed OPSCCs in Northern Europe and in North America are HPV related [1-4]. However, tobacco smoking and heavy alcohol use are still major risk factors for the development of OPSCC, especially HPV-negative OPSCC [5, 6]. Survival and recurrence-free rates of HPV-positive OPSCC are 
significantly better than its HPV-negative counterparts [6-8]. Therefore, developing management and post-treatment surveillance for these patients (particularly for the HPV-negative subgroup) warrants the search for new prognostic markers.

Previous studies have indicated that matrix metalloproteinases (MMPs) and tissue inhibitors of metalloproteinases (TIMPs) exert an important role in tumor pathogenesis and patient survival in various cancers, including head and neck cancers [9-11]. MMPs are a group of zinc-containing genetically distinct but structurally related proteolytic enzymes that degrade almost all extracellular matrix proteins [12]. These proteins may also have a direct cell-signalling effect on various cell-surface proteins, such as cluster of differentiation (CD)44 and integrins [13, 14]. Additionally, MMPs and TIMPs affect apoptosis, cancer cell growth, and immune surveillance, which in turn can promote invasion and metastasis $[9,15,16]$. Increased expression of certain MMPs can be detected in most human cancers, and their overexpression is associated with poor prognosis $[9,17,18]$. On the other hand, regardless of the active role of various MMPs in tumor progression, matrix metalloproteinase-8 (MMP-8) may have antitumor activity [19-21]. MMP-8 may modulate tumor cell adhesion and invasion by processing non-matrix bioactive inflammatory mediators [21-23]. Thus, the role of MMPs in cancer is very complex. This is also evident based on the finding that high tumoral immunoexpression of tissue inhibitor of metalloproteinase-1 (TIMP-1), which is an inhibitor of various MMPs [24, 25], is associated with poor prognosis in various cancers [26, 27]. These findings are consistent with observations indicating that cancer patients with high TIMP-1 serum levels $[11,27-30]$ are associated with poor prognosis. This may be explained by the additional ability of TIMP-1, which is an inhibitor of various MMPs, to function as a growth factor by binding to the cell surface ligand CD63 [31, 32]. This binding results in the activation of intracellular focal adhesion kinase (FAK) that can promote cancer progression [33, 34]. Overall, different serum levels of MMPs and TIMP-1 may serve as potential prognostic markers in different cancers.

To the best of our knowledge, the role of MMP- 8 and TIMP-1 in OPSCC is unknown. To evaluate their role as prognostic factors, we studied serum levels of MMP-8 and TIMP- 1 and their expression in OPSCC tumor tissue. Our specific aim was to study the association of MMP-8 and TIMP-1 with prognosis in HPV-positive and HPV-negative OPSCC.

\section{Materials and methods}

\section{Patients}

Patients with consecutive biopsy-proven OPSCC diagnosed and treated with curative intent during a 4-year time period between March 2012 and May 2016 at the Departments of Oncology and Otorhinolaryngology-Head and Neck Surgery at the Helsinki University Hospital, Helsinki, Finland were included. The inclusion criteria were tumor tissue availability for p16 and HPV DNA PCR status determination from each tumor and collected serum samples at the time of diagnosis from each patient. A total of 90 OPSCC patients met the inclusion criteria.

Clinical data included age on date of OPSCC diagnosis, sex, history of tobacco smoking and heavy use of alcohol, tumor-related factors, the date of treatment completion, and details on follow-up. All the data were collected from medical records and it is partly the same as in our previous reports $[35,36]$. Tumor stage was determined according to the 8 th edition of the American Joint Committee on Cancer staging [37]. Treatment modalities were dichotomized to radiotherapy with or without cisplatin-based chemotherapy and surgery with or without postoperative (chemo)radiotherapy.

Follow-up time was determined from the date of treatment completion to the date of last follow-up or death. Both follow-up time and follow-up protocol were adopted from our previous report [35].

\section{MMP-8 and TIMP-1 serum concentrations}

Sera were extracted from peripheral blood samples by centrifugation at $1600 \mathrm{~g}$ for $10 \mathrm{~min}$ and stored at $-70{ }^{\circ} \mathrm{C}$. An immunofluorometric assay [38, 39] and an enzyme-linked immunosorbent assay kit (GE Healthcare UK Limited, Buckinghamshire, UK) were used to determine MMP-8 and TIMP-1 serum concentrations, respectively. All analyses were performed in duplicate. Serum concentrations are shown as $\mathrm{pmol} / \mathrm{l}(\mathrm{pM})$.

\section{HPV DNA genotyping}

HPV DNA was detected by PCR from tumor tissue samples. Multiplex HPV Genotyping $\mathrm{Kit}^{\circledR}$ (DiaMex GmbH, Germany) was used to detect 24 different HPV genotypes. The method detects following low-risk HPV genotypes: 6, $11,42,43,44$, and 70, and following high-risk HPV genotypes: $16,18,26,31,33,35,39,45,51,52,53,56,58,59$, $66,68,73$ and 82 . The method is described previously in more detail [36]. For the present study, HPV DNA positivity was summarized as HPV positivity for any high-risk type.

\section{Immunohistochemistry of p16, MMP-8, and TIMP-1}

p16-INK4a status was determined by immunohistochemistry (IHC) on paraffin-embedded formalin-fixed tissue samples. Tissue slides were cut, deparaffinized, and rehydrated according to routine protocol [40]. The treated slides were heated in Tris- $\mathrm{HCl}$ buffer ( $\mathrm{pH} 8.5)$ by PreTreatment module 
(Lab Vision Corp., UK Ltd, UK). Monoclonal mouse antihuman p16INK4a (9517 CINtec Histology Kit, MTM laboratories, Germany) was used as a primary antibody and p16 expression was considered positive if $>70 \%$ of tumor cells were strongly positive, as also described previously [36, 40]. Immunohistochemical staining and Western immunoblot of TIMP-1 were analyzed from tissue microarray (TMA) blocks and Monoclonal Mouse $\operatorname{IgG}_{2 \mathrm{~B}}$ (R\&D Systems, MAB970, Minneapolis, USA) was used as a primary antibody [41]. Specific polyclonal rabbit anti-human MMP-8 $[38,42]$ was used as the primary antibody for MMP-8 immunohistochemical staining of the TMA blocks and to analyze the molecular forms of MMP- 8 by Western immunoblot. Western blotting for both TIMP-1 and MMP-8 were performed by the ECL-Western blotting analysis system as described earlier [42]. The proteins in the SDS-PAGE-gels were treated by electrophoresis, followed by membrane reaction with the primary antibody (1:500) after the proteins were first electrotransferred onto a nitrocellulose mebrane (Bio-Rad Laboratories, Richmond, California) and blocked with $3 \%$ gelatin as previously described [42]. Alkaline phosphatase conjugated antibody was used for secondary immunoreaction with the proteins and the final quantitation was performed by a densitometry (Bio-Rad Model GS-700 Imaging Densitometer, Hercules, CA) after the proteins were first visualized using 5-bromo-4-chloro-3-indonyl-phosphate disodium salt (Sigma) and nitro blue tetrazolium (Sigma, St. Louis, Missouri) [42, 43]. Gingival tissue was used as a positive control for both MMP-8 and TIMP-1. A slide in diluent without primary antibody in each immunostaining served as a negative control.

\section{Immunoscoring}

TMA slides were independently evaluated and scored by two researchers (Timo Carpén and Jaana Hagström). Each tumor had six 1-mm punches scored and the slides were re-scored in case of discrepancy. Tumor and stromal cells were scored separately. The scoring of TIMP- 1 and MMP-8 in tumor tissue was assessed as follows: negative (0), mild positivity (1), moderate positivity (2) and strong positivity (3). MMP-8 and TIMP-1 scoring in the inflammatory cells were assessed regarding to the number of positive cells as follows: negative (0), 1-20 positive cells (1), 20-100 positive cells (2) and $>100$ positive cells (3).

\section{Statistical analysis}

All statistical analyses were performed with IBM SPSS Statistics 25 (IBM, Somers, IL, USA). The endpoints were overall survival (OS) and disease-free survival (DFS). OS was defined as the time from the completion of treatment to death from any cause. DFS was defined as the time from the completion of treatment to the first recurrence or death from any cause. A Cox proportional hazard model was used to evaluate hazard ratios (HRs) in the univariate and multivariate setting. To improve HPV specificity without affecting the sensitivity the combined HPV status of p16 and HPV DNA PCR was used as previously highly recommended $[44,45]$. Tumors that are both HPV DNA positive and 16 positive were classified as HPV-positive $(\mathrm{HPV}+)$; and the other combinations were classified as HPV-negative (HPV -) as defined in previous reports $[44,46]$. Logarithmic transformations were applied for MMP-8 and TIMP-1 serum concentrations to eliminate positive skewness. Survival curves were drawn using the Kaplan-Meier estimate and the statistical significance was calculated with the log-rank test. Receiver operating characteristic curves were used to assess the optimal cut-off serum concentration to discriminate patients with favorable and unfavorable survival. The value that maximizes Youden index (sensitivity + specificity-1) was chosen as an optimal cut-off. A comparison of medians of continuous variables with categorical variables was performed using Mann-Whitney $U$ test and Kruskal-Wallis test when suitable. The two-sample $t$ test was used to compare means of normally distributed continuous variables between two independent groups. Chi-squared and Fisher's exact tests were used for categorical data cross tabulation. A two-sided $p$-value $<0.05$ was considered as the level of significance.

\section{Results}

\section{Patient characteristics}

Of the total 90 patients, the majority $(n=66,73.3 \%)$ were male. Mean age was 61.8 years (range, 36.6-84.7 years). Sixty-six (73.3\%) of the tumors were p16 positive and 24 (26.7\%) were p16 negative. Fifty-five (61.1\%) tumors were HPV DNA positive. The detected high-risk HPV genotypes were as follows: HPV16 $(n=51,92.7 \%), \operatorname{HPV} 18(n=1$, $1.8 \%)$, and HPV33 ( $n=3,5.5 \%)$. Fifty-three (58.9\%) tumors were both p16 positive and HPV DNA positive and were considered as HPV positive. The remaining 37 (41.1\%) tumors were classified as HPV negative and they included the following combinations of HPV and p16 status: p16-/ HPV DNA- $(n=22,24.4 \%), \mathrm{p} 16+/$ HPV DNA- $(n=13$, $14.4 \%)$, and p16-/HPV DNA + $(n=2,2.2 \%)$. Smoking, heavy alcohol consumption, and advanced stage disease (III-IV) were significantly more common among patients with HPV-negative OPSCC than among patients with HPVpositive OPSCC. Patient characteristics and tumor-related factors are presented in Table 1. 


\section{TIMP-1 is immunoexpressed in the majority of the tumors and MMP-8 in the surrounding cells}

Of the 90 tumors, 84 (93.3\%) were available for TIMP-1 IHC. TIMP-1 immunoexpression was detected as cytoplasmic positivity in majority of the tumor cells $(n=61,84.5 \%$, Fig. 1). However, significant differences in the expression between HPV-positive and HPV-negative tumors were not found. Only very few lymphocytes showed TIMP-1 immunopositivity, and thus their immunoscoring was not considered appropriate.

Eighty-three (92.2\%) tumors were available for MMP-8 IHC. MMP-8 immunoexpression was absent in tumor cells. However, MMP-8 expression positivity was observed in the inflammatory polymorphonuclear leukocytes adjacent to the tumor in the majority $(n=76,91.6 \%$, Fig. 1) of samples. While a trend towards higher MMP-8 immunoexpression in the inflammatory cells among HPV-negative tumors compared with HPV-positive tumors was observed, the difference was statistically insignificant $(p=0.052)$. The levels of TIMP-1 and MMP-8 immunoexpression and differences between HPV-positive and HPV-negative patients are presented in Table 1.

\section{TIMP-1 serum levels are several fold higher compared with MMP-8 serum levels}

The mean and the median MMP-8 serum levels for HPVpositive patients were $761 \mathrm{pM}$ (Standard deviation [SD] 743 ) and $762 \mathrm{pM}$ (range, 123-3391 pM), respectively. The mean and the median MMP-8 serum levels for HPV-negative patients were $844 \mathrm{pM}$ (SD 699) and $658 \mathrm{pM}$ (range, 178-3477 pM), respectively.

TIMP-1 serum levels were approximately 10 times higher than MMP-8 serum levels. The mean and the median TIMP-1 serum levels for HPV-positive patients were $8206 \mathrm{pM}$ (SD 4291) and $7054 \mathrm{pM}$ (range, 3274-33,498 pM), respectively. The mean and the median TIMP-1 level for HPV-negative patients were 7869 pM (SD 3128) and 7271 pM (range, 2712-16,322 pM), respectively. However, significant differences in TIMP-1 serum levels or in MMP-8 serum levels were not observed between HPV-positive and HPV-negative patients (Table 1).

\section{TIMP-1, MMP-8, and survival}

The median follow-up time was 37 months (range, 0-62 months). Univariate analysis was first performed for the entire patient cohort. Univariate analysis revealed that differences in TIMP-1 serum levels, stage, age, HPV status, and smoking status were statistically significantly associated with OS. In contrast, differences in TIMP-1 tissue expression, MMP-8 tissue expression, or MMP-8 serum levels did
Table 1 Clinicopathological data and TIMP-1 and MMP-8 serum concentrations and immunoexpressions according to HPV status

\begin{tabular}{|c|c|c|c|c|c|}
\hline Variable & $\mathrm{HPV}+$ & $\%$ & HPV - & $\%$ & $p$-value \\
\hline Number of patients & 53 & 58.1 & 37 & 41.9 & \\
\hline Mean age at diagnosis & 61.6 & & 62.2 & & 0.755 \\
\hline \multicolumn{6}{|l|}{ Sex } \\
\hline Male & 43 & 81.1 & 23 & 62.2 & \\
\hline Female & 10 & 11.1 & 14 & 37.8 & $0.045^{*}$ \\
\hline \multicolumn{6}{|l|}{ Smoking } \\
\hline Non-smoker & 20 & 37.7 & 8 & 21.6 & \\
\hline Ex-smoker & 24 & 45.3 & 6 & 16.2 & \\
\hline Current smoker & 9 & 17.0 & 23 & 62.2 & $<0.001 * *$ \\
\hline \multicolumn{6}{|l|}{ Heavy alcohol use } \\
\hline Never & 28 & 70.0 & 15 & 44.1 & \\
\hline Former & 2 & 5.0 & 8 & 23.5 & \\
\hline Current & 10 & 25.0 & 11 & 32.4 & $0.028^{*}$ \\
\hline \multicolumn{6}{|l|}{$T$ class } \\
\hline $\mathrm{T} 1-\mathrm{T} 2$ & 35 & 66.0 & 23 & 62.2 & \\
\hline $\mathrm{T} 3-\mathrm{T} 4$ & 18 & & & & \\
\hline $\mathrm{T} 2$ & 34.0 & 14 & 37.8 & 0.705 & \\
\hline \multicolumn{6}{|l|}{$N$ class } \\
\hline N0-N1 & 50 & 94.3 & 24 & 64.9 & \\
\hline $\mathrm{N} 2-\mathrm{N} 3$ & 3 & 5.7 & 13 & 35.1 & $<0.001 * *$ \\
\hline \multicolumn{6}{|l|}{ Stage } \\
\hline I-II & 44 & 83 & 19 & 51.4 & \\
\hline III-IV & 9 & 17.0 & 18 & 48.6 & $0.001 * *$ \\
\hline \multicolumn{6}{|l|}{ Grade } \\
\hline I & 1 & 1.9 & 2 & 5.4 & \\
\hline II & 3 & 5.7 & 12 & 32.4 & \\
\hline III & 49 & 92.5 & 23 & 62.2 & $<0.001 * *$ \\
\hline \multicolumn{6}{|l|}{ Treatment } \\
\hline (C)RT & 39 & 73.6 & 23 & 62.2 & \\
\hline $\mathrm{Sx}+-(\mathrm{C}) \mathrm{RT}$ & 14 & 26.4 & 14 & 37.8 & 0.249 \\
\hline $\begin{array}{l}\text { TIMP-1 serum level } \\
(\mathrm{pM})\end{array}$ & 8206 & & 7869 & & 0.879 \\
\hline $\begin{array}{l}\text { MMP-8 serum level } \\
(\mathrm{pM})\end{array}$ & 762 & & 844 & & 0.253 \\
\hline \multicolumn{6}{|c|}{ TIMP-1 immunoexpression } \\
\hline 0 & 7 & 13.5 & 6 & 18.8 & \\
\hline 1 & 30 & 57.7 & 20 & 62.4 & \\
\hline 2 & 15 & 28.8 & 6 & 18.8 & \\
\hline 3 & 0 & 0 & 0 & 0 & 0.541 \\
\hline \multicolumn{6}{|c|}{ MMP-8 immunoexpression } \\
\hline 0 & 3 & 5.9 & 4 & 12.5 & \\
\hline 1 & 34 & 66.7 & 13 & 40.6 & \\
\hline 2 & 13 & 25.5 & 11 & 34.4 & \\
\hline 3 & 1 & 2.0 & 4 & 4.8 & 0.052 \\
\hline
\end{tabular}

(C) chemo, $M M P-8$ matrix metalloproteinase-8, $R T$ radiotherapy, $S x$ surgery, TIMP-1 tissue inhibitor of metalloproteinase-1

Serum levels of TIMP-1 and MMP-8 are as presented as mean concentrations. TIMP-1 immunoexpression was scored from the tumor tissue. MMP-8 immunoexpression was scored from the inflammatory cells adjacent to the tumor tissue. $p<0.05^{*}, p<0.01^{* *}$ 

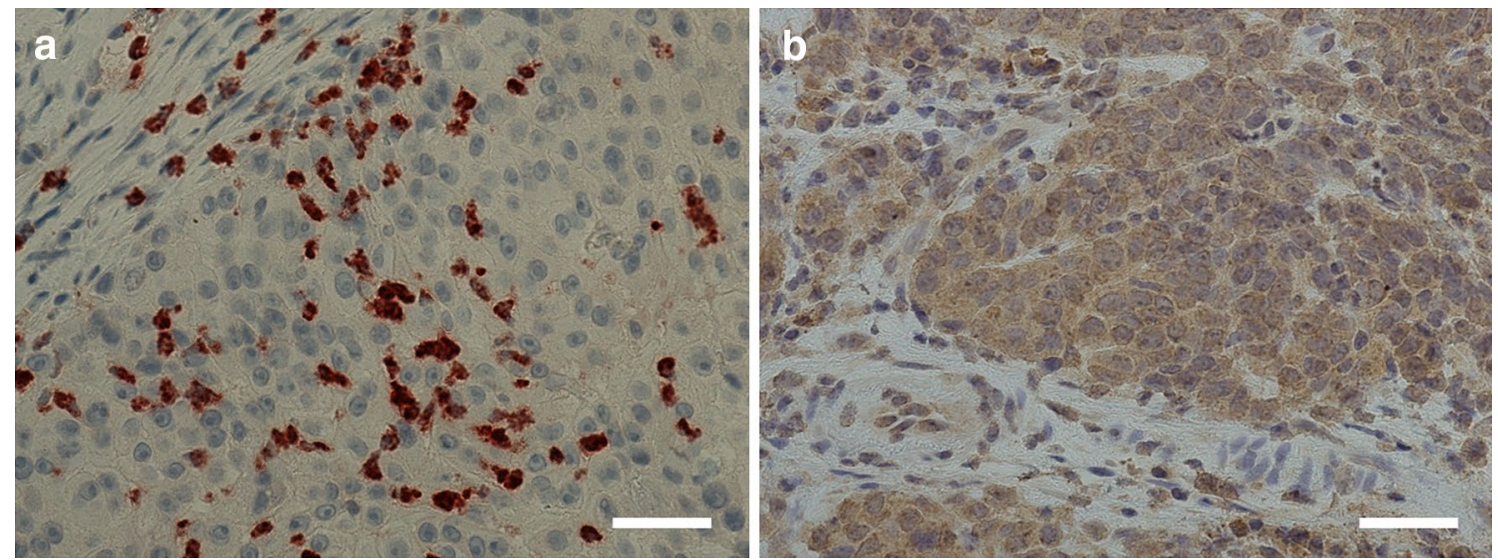

Fig. 1 a Positive matrix metalloproteinase-8 (MMP-8) immunoexpression in the cells surrounding the tumor tissue. b Positive tissue inhibitor of metalloproteinase-1 (TIMP-1) immunoexpression in tumor tissue. Scale bar length $50 \mu \mathrm{m}$. Magnification $\times 400$

not reach statistical significance (Table 2). A multivariate Cox regression analysis was performed employing all variables that were statistically significant in univariate analysis. Multivariate analysis revealed that high TIMP-1 serum levels were independently associated with poorer OS (adjusted HR 3.6, 95\% CI 1.0-12.00, $p=0.039$ ) (Table 2).

\section{High TIMP-1 serum levels are associated with poorer OS and DFS among HPV-negative patients}

Multivariate analysis was performed separately for HPVpositive and HPV-negative groups to evaluate if TIMP-1 serum levels were associated with differences in HRs between these groups (Table 2). High TIMP-1 serum levels were independently associated with poorer OS (adjusted HR 3.6, 95\% CI 1.0-117.4, $p=0.011$ ) among HPV-negative patients (Table 2). TIMP-1 serum levels did not have any impact on OS among HPV-positive patients.

Additionally, a similar multivariate analysis was performed to evaluate differences in DFS. High TIMP-1 serum levels were independently associated with poorer DFS (adjusted HR 8.7, 95\% CI 1.3-57.1, $p=0.024$ ) among HPVnegative patients. TIMP-1 serum levels did not have any impact on DFS among HPV-positive patients.

\section{TIMP-1 serum level cut-off points and survival}

A TIMP-1 serum cut-off value of $7000 \mathrm{pM}$ was found to maximize Youden index. In addition, a TIMP-1 serum level of $7000 \mathrm{pM}$ was close to the median serum level of both HPV-positive and HPV-negative patients. Consequently, it was chosen as an optimal cut-off concentration to discriminate patients into favourable and unfavorable survival groups for further Kaplan-Meier analyses. HPV-negative patients with high TIMP-1 serum levels $(>7000 \mathrm{pM})$ had significantly poorer OS $(p=0.006)$ and DFS $(p=0.010)$ when compared with patients with lower serum levels $(\leq 7000 \mathrm{pM})$ by Kaplan-Meier method. Similar statistically significant associations were not found in HPV-positive patients. Survival curves drawn by Kaplan-Meier method are presented in Fig. 2.

\section{Discussion}

This prospective study provides new evidence on the potential of TIMP-1 serum levels to serve as an independent prognostic biomarker for OPSCC. TIMP-1 serum levels were found to be a significant independent prognostic marker for OS and DFS in HPV-negative OPSCC patients. Similar results regarding the prognostic value of TIMP-1 serum and plasma levels have also been found in various other cancers $[11,29,30]$, including head and neck cancers [27, 28]. However, to the best of our knowledge, this is the first study that is focused on OPSCC only and that compares the prognostic value both in HPV-positive and HPV-negative patients.

The strengths of the present study were the prospective setting with a relatively long follow-up period and availability of both p16 and HPV-DNA status for all tumors. Regarding limitations, MMP-8 and TIMP-1 IHC were not available for all patients and the number of patients was relatively small, which limited more extensive statistical analyses.

TIMP-1 has been reported to have two distinct functions. In addition to directly binding to various MMPs and inhibiting their function, TIMP-1 exerts a specific growth factor function by interacting with the cell surface molecule CD63 and thereby activates intracellular signaling through FAK leading to cell proliferation [24, 25, 31, 32]. It is notable that although TIMP-1 inhibits the proteolytic function of MMP-8, in the present study the serum concentration of 
Table 2 Univariate and multivariate Cox regression analysis for overall survival in the whole patient cohort and separately in HPV-positive and HPV-negative patients

\begin{tabular}{|c|c|c|c|c|c|c|c|c|c|c|c|c|}
\hline & \multirow{2}{*}{\multicolumn{3}{|c|}{$\frac{\text { Univariate analysis }}{\text { All patients }}$}} & \multirow{2}{*}{\multicolumn{3}{|c|}{$\frac{\text { Multivariate analysis }}{\text { All patients }}$}} & \multirow{2}{*}{\multicolumn{3}{|c|}{$\frac{\text { Multivariate analysis }}{\text { HPV-positive patients }}$}} & \multirow{2}{*}{\multicolumn{3}{|c|}{$\frac{\text { Multivariate analysis }}{\text { HPV-negative patients }}$}} \\
\hline & & & & & & & & & & & & \\
\hline & HR & $95 \% \mathrm{CI}$ & $p$-value & HR & $95 \% \mathrm{CI}$ & $p$-value & HR & $95 \% \mathrm{CI}$ & $p$-value & HR & $95 \% \mathrm{CI}$ & $p$-value \\
\hline Age & 1.1 & $1.0-1.1$ & $0.003^{*}$ & 1.1 & $1.0-1.1$ & $0.004 * *$ & 1.1 & $0.9-1.2$ & 0.119 & 1.0 & $0.9-1.1$ & 0.249 \\
\hline \multicolumn{13}{|l|}{ Sex } \\
\hline Female versus male & 1.4 & $0.6-3.3$ & 0.499 & & & & & & & & & \\
\hline Smoking & & & $0.003^{*}$ & & & $0.008 * *$ & & & $0.016^{*}$ & & & 0.399 \\
\hline Ex-smoker versus never & 1.3 & $0.3-5.8$ & 0.734 & 2.0 & $0.4-9.7$ & 0.380 & 3.0 & $0.3-30.0$ & 0.347 & 2.7 & $0.2-35.4$ & 0.451 \\
\hline Current versus never & 5.5 & $1.6-18.9$ & $0.007 *$ & 6.7 & $1.8-24.4$ & $0.004 * *$ & 14.5 & $1.7-127.6$ & $0.016^{*}$ & 3.1 & $0.6-16.6$ & 0.176 \\
\hline \multicolumn{13}{|l|}{ T class } \\
\hline $\mathrm{T} 3-\mathrm{T} 4$ versus $\mathrm{T} 1-\mathrm{T} 2$ & 1.3 & $0.6-2.9$ & 0.578 & & & & & & & & & \\
\hline \multicolumn{13}{|l|}{$N$ class } \\
\hline N2-N3 versus N0-N1 & 1.9 & $0.8-4.9$ & 0.166 & & & & & & & & & \\
\hline \multicolumn{13}{|l|}{ Stage } \\
\hline III-IV versus I-II & 3.4 & $1.5-7.8$ & $0.004 *$ & 2.4 & $0.9-5.9$ & 0.068 & 1.7 & $0.3-10.5$ & 0.562 & 8.7 & $1.5-50.6$ & $0.017 *$ \\
\hline \multicolumn{13}{|l|}{ Treatment } \\
\hline $\mathrm{Sx}+-(\mathrm{C}) \mathrm{RT}$ versus $(\mathrm{C}) \mathrm{RT}$ & 1.7 & $0.7-3.8$ & 0.243 & & & & & & & & & \\
\hline \multicolumn{13}{|l|}{$H P V$} \\
\hline HPV - versus HPV + & 2.6 & $1.1-6.1$ & $0.024^{*}$ & 1.1 & $0.4-3.1$ & 0.810 & & & & & & \\
\hline TIMP-1 serum level & 2.7 & $1.1-6.9$ & $0.037 *$ & 3.6 & $1.1-12.0$ & $0.039^{*}$ & 1.1 & $0.1-12.1$ & 0.958 & 14.7 & $1.8-117.4$ & $0.011 *$ \\
\hline MMP-8 serum level & 1.1 & $0.66-1.8$ & 0.739 & & & & & & & & & \\
\hline \multicolumn{13}{|l|}{ TIMP-1 immunoexpression } \\
\hline $2-3$ versus $0-1$ & 1.5 & $0.6-3.8$ & 0.340 & & & & & & & & & \\
\hline \multicolumn{13}{|l|}{ MMP-8 immunoexpression } \\
\hline $2-3$ versus $0-1$ & 1.5 & $0.6-3.6$ & 0.360 & & & & & & & & & \\
\hline
\end{tabular}

(C) chemo, $C I$ confidence interval, $H R$ hazard ratio, $M M P-8$ matrix metalloproteinase- $8, R T$ radiotherapy, $S x$ surgery, TIMP-1 tissue inhibitor of metalloproteinase-1

Serum TIMP-1 and MMP-8 concentrations are log-transformed. $p<0.05^{*}, p<0.01^{* *}$

MMP-8 was not associated with prognosis. In contrast to other MMPs that in general are associated with promoting cancer invasion and metastasis [9, 17, 18], MMP-8 has been associated with a favorable outcome in various cancers [20, 21].

Although, serum levels of MMP-8 were not associated with survival in the present study, we cannot formally exclude that the association between TIMP-1 and survival is somehow caused by TIMP- 1 inhibiting the MMP- 8 function. However, our observation that elevated TIMP-1 serum levels, but not MMP-8, are associated with poorer prognosis raises the possibility that the association between TIMP-1 serum concentration and survival is not mediated by the inhibition of MMPs, but instead by interacting with its cell surface receptor CD63 leading to FAK activation. FAK has a key role in immunoevasion and tumor growth and may be a possible target for immunotherapy [14, 47, 48].

In the present study, multivariate analysis revealed that increased TIMP-1 serum levels were independently associated with poorer prognosis in patients with HPV-negative tumors. However, there was also a trend of increased TIMP-1 serum levels and poorer survival in patients with HPV-positive tumors. However, this trend was clearly weaker than in patients with HPV-negative tumors. This weak trend did not reach statistical significance in the present study but might show a stronger effect in a larger patient cohort. Nevertheless, increased TIMP-1 serum levels more strongly associated with poorer prognosis in patients with HPV-negative tumors than in those with HPV-positive tumors. It is possible that the oncogenic changes associated with HPV transformation are sufficiently strong leading to oncogenesis without TIMP-1 up-regulation. The oncogenic changes leading to TIMP-1 upregulation may be more responsible for cancer progression in HPV-negative tumors. In addition, it is notable that on average HPV-negative tumors have more oncogenic mutations and the mutation profile is different when compared with HPV-positive tumors [49-51]. Additionally, we measured TIMP-1 tumor immunoexpression and this appeared to be positive in the majority of tumor samples. However, in contrast to some previous studies [26, 27,34] we did not observe 

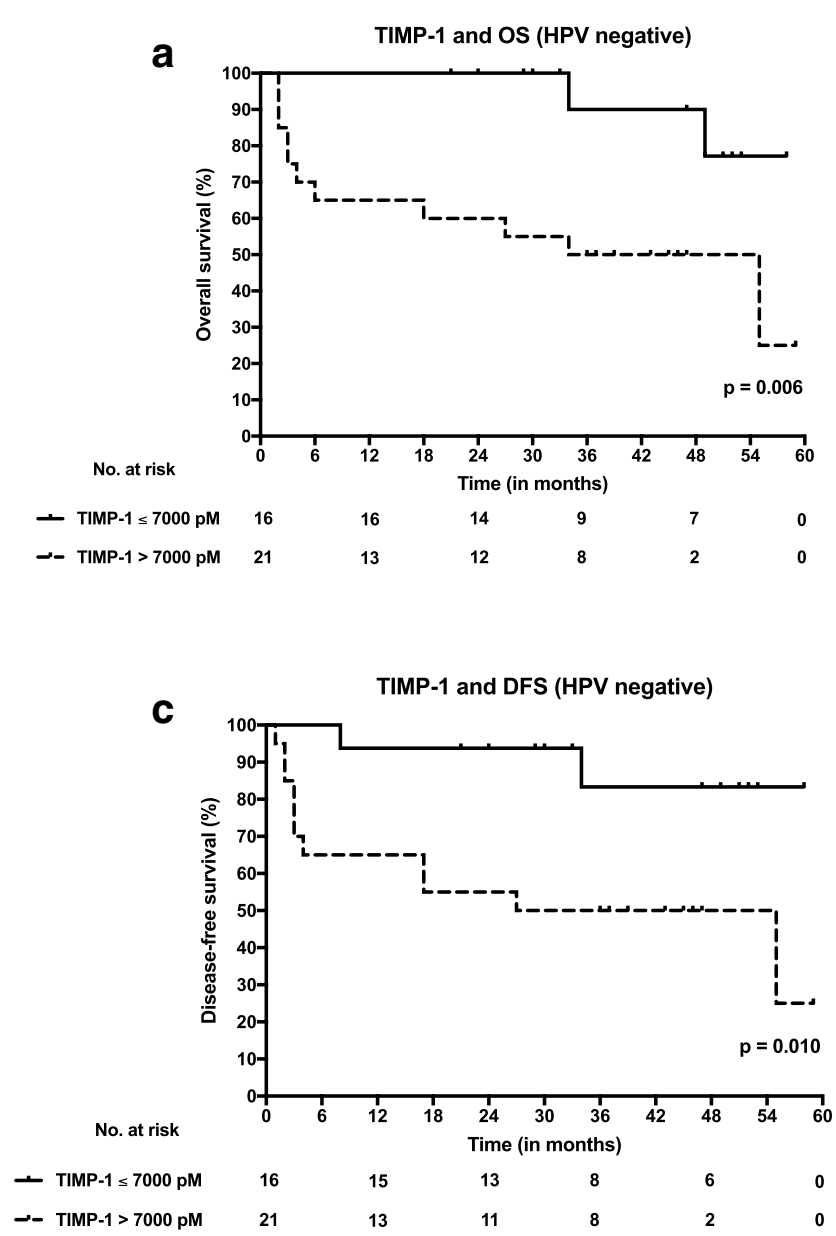

Fig. 2 Overall survival (OS) and disease-free survival (DFS) curves according to high $(>7000 \mathrm{pM})$ and low $(\leq 7000 \mathrm{pM})$ serum levels of tissue inhibitor of metalloproteinase-1 (TIMP-1) both in HPVpositive and HPV-negative OPSCC. a TIMP-1 serum level and OS

an association between different TIMP-1 tumor immunoexpression levels and prognosis despite our observing an association between different TIMP-1 serum levels and survival. There may be several explanations for this. One possibility is that TIMP-1 is rapidly secreted from OPSCC tumor cells and that tissue immunoexpression does not truly reflect the production rate of TIMP-1 in OPSCC tumor cells.

The level of MMP-8 immunoexpression in inflammatory cells appeared to be higher in patients with a HPV-negative tumors than those with HPV-positive tumors. However, the difference was not statistically significant. The differences in the biological and pathophysiological backgrounds of HPV-positive and HPV-negative tumors may explain this phenomenon but a larger patient cohort may be necessary to reach statistical significance.

p16 overexpression, which is characteristic for HPV-positive tumors, is an established independent prognostic factor for OPSCC [6, 8]. Besides p16 and HPV, other comprehensively validated prognostic molecular markers for OPSCC
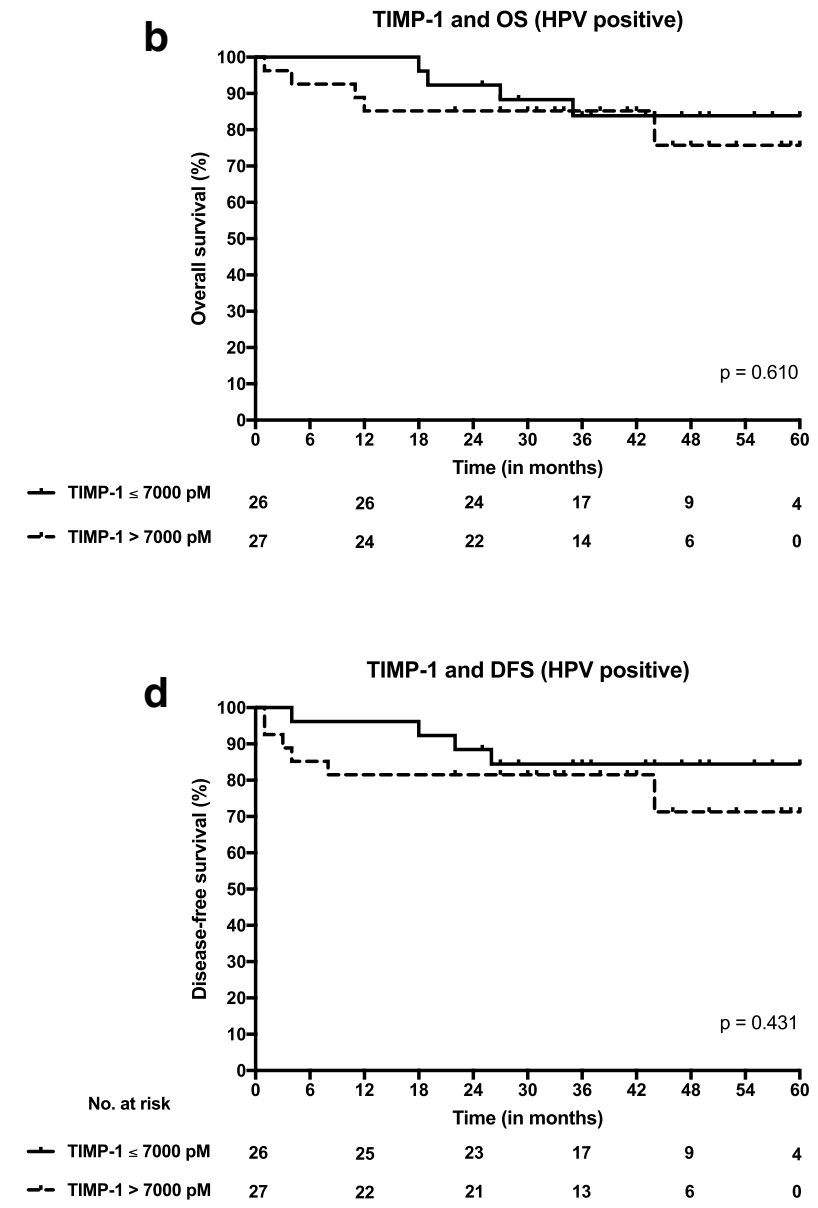

in HPV-negative OPSCC. b TIMP-1 serum level and OS in HPVpositive OPSCC. c TIMP-1 serum level and DFS in HPV-negative OPSCC. d TIMP-1 serum level and DFS in HPV-positive OPSCC

are currently unknown. The survival rates of HPV-negative OPSCC patients have remained generally poor despite of developments in treatment modalities [4, 7, 8]. Thus, there is a clear demand for new prognostic markers, particularly for HPV-negative patients.

\section{Conclusions}

This study provides new evidence for the potential of TIMP-1 serum levels as an independent prognostic biomarker for HPV-negative OPSCC patients. This should be studied in a larger cohort in a multi-center setting to confirm and validate these findings.

Acknowledgements Open access funding provided by University of Helsinki including Helsinki University Central Hospital. The authors thank Päivi Peltokangas for technical assistance and Tero Vahlberg for technical guidance in statistical analyses. 
Author's contributions TC: collection of clinical data, data quality control, statistical data analysis, interpretation of results, and writing of the manuscript; TS: serum sample analysis, interpretation of results, and participating in writing the manuscript; LJ: data quality control, statistical data analysis, interpretation of results, and participating in writing the manuscript; TT: preparation of the serum samples; $\mathrm{CH}$ : immunohistochemistry, interpretion of results, and writing the manuscript; SS: HPV DNA analysis and writing the manuscript, JT: data analysis; HM: immunohistochemistry and data analysis, AM: participating in study design planning and writing the manuscript; $\mathrm{JH}$ : design of the study, interpretation of results, and writing of the manuscript. PSM: design of the study, collection of serum samples, interpretation of results, and, writing the manuscript. All authors have read and approved the final manuscript.

Funding This study was supported by Grants from the Helsinki University Hospital Research Fund, The Finnish OtorhinolaryngologyHead and Neck Surgery (ORL-HNS) Foundation, the Finska Läkaresällskapet, and the Ida Montin Foundation.

\section{Compliance with ethical standards}

Conflict of interest The authors declare that they have no conflict of interest.

Ethical approval and ethical standards The Research Ethics Board of the Hospital District of Helsinki and Uusimaa, Finland approved the study design (Dnr: 51/13/03/02/2013) and an institutional study permission was granted. All applicable ethical guidelines and legislation were followed, and the study design complies with the Declaration of Helsinki.

Informed consent Informed consent was obtained from all participants included in the study. Informed consent included the permission to take blood samples. Additionally, it included permission to use the blood samples and tumor samples of the participants for further analyses and research purposes.

Open Access This article is distributed under the terms of the Creative Commons Attribution 4.0 International License (http://creativeco mmons.org/licenses/by/4.0/), which permits unrestricted use, distribution, and reproduction in any medium, provided you give appropriate credit to the original author(s) and the source, provide a link to the Creative Commons license, and indicate if changes were made.

\section{References}

1. Mehanna H, Beech T, Nicholson T, El-Hariry I, McConkey C, Paleri V, Roberts S (2013) Prevalence of human papillomavirus in oropharyngeal and nonoropharyngeal head and neck cancersystematic review and meta-analysis of trends by time and region. Head Neck 35(5):747-755. https://doi.org/10.1002/hed.22015

2. Habbous S, Chu KP, Qiu X, La Delfa A, Harland LT, Fadhel E, Hui A, Perez-Ordonez B, Weinreb I, Liu FF, Waldron J, O'Sullivan B, Goldstein D, Xu W, Huang SH, Liu G (2013) The changing incidence of human papillomavirus-associated oropharyngeal cancer using multiple imputation from 2000 to 2010 at a Comprehensive Cancer Centre. Cancer Epidemiol 37(6):820829. https://doi.org/10.1016/j.canep.2013.09.011

3. Stein AP, Saha S, Kraninger JL, Swick AD, Yu M, Lambert PF, Kimple RJ (2015) Prevalence of human papillomavirus in oropharyngeal cancer: a systematic review. Cancer J 21(3):138146. https://doi.org/10.1097/PPO.0000000000000115

4. Jouhi L, Halme E, Irjala H, Saarilahti K, Koivunen P, Pukkila M, Hagstrom J, Haglund C, Lindholm P, Hirvikoski P, Vaittinen S, Ellonen A, Tikanto J, Blomster H, Laranne J, Grenman R, Makitie A, Atula T (2018) Epidemiological and treatment-related factors contribute to improved outcome of oropharyngeal squamous cell carcinoma in Finland. Acta Oncol 57(4):541-551. https://doi.org/10.1080/0284186x.2017.14006 88

5. Gillison ML, D'Souza G, Westra W, Sugar E, Xiao W, Begum S, Viscidi R (2008) Distinct risk factor profiles for human papillomavirus type 16-positive and human papillomavirus type 16-negative head and neck cancers. J Natl Cancer Inst 100(6):407-420. https ://doi.org/10.1093/jnci/djn025

6. Fakhry C, Westra WH, Li S, Cmelak A, Ridge JA, Pinto H, Forastiere A, Gillison ML (2008) Improved survival of patients with human papillomavirus-positive head and neck squamous cell carcinoma in a prospective clinical trial. J Natl Cancer Inst 100(4):261-269. https://doi.org/10.1093/jnci/djn011

7. Ragin CC, Taioli E (2007) Survival of squamous cell carcinoma of the head and neck in relation to human papillomavirus infection: review and meta-analysis. Int J Cancer 121(8):1813-1820. https ://doi.org/10.1002/ijc.22851

8. Ang KK, Harris J, Wheeler R, Weber R, Rosenthal DI, NguyenTan PF, Westra WH, Chung CH, Jordan RC, Lu C, Kim H, Axelrod R, Silverman CC, Redmond KP, Gillison ML (2010) Human papillomavirus and survival of patients with oropharyngeal cancer. N Engl J Med 363(1):24-35. https://doi.org/10.1056/NEJMo a0912217

9. Egeblad M, Werb Z (2002) New functions for the matrix metalloproteinases in cancer progression. Nat Rev Cancer 2(3):161-174. https://doi.org/10.1038/nrc745

10. Lopez-Otin C, Bond JS (2008) Proteases: multifunctional enzymes in life and disease. J Biol Chem 283(45):30433-30437. https://doi. org/10.1074/jbc.R800035200

11. Lempinen M, Lyytinen I, Nordin A, Tervahartiala T, Makisalo H, Sorsa T, Isoniemi H (2013) Prognostic value of serum MMP-8, -9 and TIMP-1 in patients with hepatocellular carcinoma. Ann Med 45(7):482-487. https://doi.org/10.3109/07853890.2013.823779

12. Visse R, Nagase H (2003) Matrix metalloproteinases and tissue inhibitors of metalloproteinases: structure, function, and biochemistry. Circ Res 92(8):827-839. https://doi.org/10.1161/01. RES.0000070112.80711.3D

13. Karadag A, Fedarko NS, Fisher LW (2005) Dentin matrix protein 1 enhances invasion potential of colon cancer cells by bridging matrix metalloproteinase-9 to integrins and CD44. Cancer Res 65(24):11545-11552. https://doi.org/10.1158/0008-5472. Can-05-2861

14. Chirco R, Liu XW, Jung KK, Kim HR (2006) Novel functions of TIMPs in cell signaling. Cancer Metastasis Rev 25(1):99-113. https://doi.org/10.1007/s10555-006-7893-x

15. Liotta LA, Tryggvason K, Garbisa S, Hart I, Foltz CM, Shafie S (1980) Metastatic potential correlates with enzymatic degradation of basement membrane collagen. Nature 284:67. https://doi. org $/ 10.1038 / 284067 \mathrm{a} 0$

16. Kessenbrock K, Plaks V, Werb Z (2010) Matrix metalloproteinases: regulators of the tumor microenvironment. Cell 141(1):5267. https://doi.org/10.1016/j.cell.2010.03.015

17. Imanishi Y, Fujii M, Tokumaru Y, Tomita T, Kanke M, Kanzaki J, Kameyama K, Otani Y, Sato H (2000) Clinical significance of expression of membrane type 1 matrix metalloproteinase and matrix metalloproteinase- 2 in human head and neck squamous cell carcinoma. Hum Pathol 31(8):895-904. https://doi.org/10.1053/ hupa.2000.9756 
18. Ahmed Haji Omar A, Haglund C, Virolainen S, Hayry V, Atula T, Kontio R, Salo T, Sorsa T, Hagstrom J (2015) MMP-7, MMP-8, and MMP-9 in oral and cutaneous squamous cell carcinomas. Oral Surg Oral Med Oral Pathol Oral Radiol 119(4):459-467. https:// doi.org/10.1016/j.oooo.2014.12.019

19. Moilanen M, Pirila E, Grenman R, Sorsa T, Salo T (2002) Expression and regulation of collagenase-2 (MMP-8) in head and neck squamous cell carcinomas. J Pathol 197(1):72-81. https://doi. org/10.1002/path.1078

20. Decock J, Hendrickx W, Vanleeuw U, Van Belle V, Van Huffel S, Christiaens MR, Ye S, Paridaens R (2008) Plasma MMP1 and MMP8 expression in breast cancer: protective role of MMP8 against lymph node metastasis. BMC Cancer 8:77. https://doi. org/10.1186/1471-2407-8-77

21. Korpi JT, Kervinen V, Mäklin H, Väänänen A, Lahtinen M, Läärä E, Ristimäki A, Thomas G, Ylipalosaari M, Åström P, LopezOtin C, Sorsa T, Kantola S, Pirilä E, Salo T (2008) Collagenase-2 (matrix metalloproteinase-8) plays a protective role in tongue cancer. Br J Cancer 98(4):766-775. https://doi.org/10.1038/ sj.bjc. 6604239

22. Vayrynen JP, Vornanen J, Tervahartiala T, Sorsa T, Bloigu R, Salo T, Tuomisto A, Makinen MJ (2012) Serum MMP-8 levels increase in colorectal cancer and correlate with disease course and inflammatory properties of primary tumors. Int J Cancer 131(4):E463E474. https://doi.org/10.1002/ijc.26435

23. Gutierrez-Fernandez A, Fueyo A, Folgueras AR, Garabaya C, Pennington CJ, Pilgrim S, Edwards DR, Holliday DL, Jones JL, Span PN, Sweep FC, Puente XS, Lopez-Otin C (2008) Matrix metalloproteinase-8 functions as a metastasis suppressor through modulation of tumor cell adhesion and invasion. Can Res 68(8):2755-2763. https://doi.org/10.1158/0008-5472.can-07-5154

24. Hayakawa T, Yamashita K, Tanzawa K, Uchijima E, Iwata K (1992) Growth-promoting activity of tissue inhibitor of metalloproteinases-1 (TIMP-1) for a wide range of cells a possible new growth factor in serum. FEBS Lett 298(1):29-32. https:// doi.org/10.1016/0014-5793(92)80015-9

25. Moore CS, Crocker SJ (2012) An alternate perspective on the roles of TIMPs and MMPs in pathology. Am J Pathol 180(1):12-16. https://doi.org/10.1016/j.ajpath.2011.09.008

26. Gouyer V, Conti M, Devos P, Zerimech F, Copin MC, Créme E, Wurtz A, Porte H, Huet G (2005) Tissue inhibitor of metalloproteinase 1 is an independent predictor of prognosis in patients with nonsmall cell lung carcinoma who undergo resection with curative intent. Cancer 103(8):1676-1684. https://doi.org/10.1002/ cncr.20965

27. Ruokolainen H, Pääkkö P, Turpeenniemi-Hujanen T (2005) Tissue inhibitor of matrix metalloproteinase-1 Is prognostic in head and neck squamous cell carcinoma: comparison of the circulating and tissue immunoreactive protein. Clin Cancer Res 11(9):3257

28. Pradhan-Palikhe P, Vesterinen T, Tarkkanen J, Leivo I, Sorsa T, Salo T, Mattila PS (2010) Plasma level of tissue inhibitor of matrix metalloproteinase-1 but not that of matrix metalloproteinase- 8 predicts survival in head and neck squamous cell cancer. Oral Oncol 46(7):514-518. https://doi.org/10.1016/j.oraloncolo gy.2010.03.002

29. McCarthy K, Maguire T, McGreal G, McDermott E, O’Higgins N, Duffy Michael J (1999) High levels of tissue inhibitor of metalloproteinase-1 predict poor outcome in patients with breast cancer. Int J Cancer 84(1):44-48. https://doi.org/10.1002/(SICI)10970215(19990219)84:1\%3c44:AID-IJC9\%3e3.0.CO;2-P

30. Manenti L, Paganoni P, Floriani I, Landoni F, Torri V, Buda A, Taraboletti G, Labianca R, Belotti D, Giavazzi R (2003) Expression levels of vascular endothelial growth factor, matrix metalloproteinases 2 and 9 and tissue inhibitor of metalloproteinases 1 and 2 in the plasma of patients with ovarian carcinoma. Eur
J Cancer 39(13):1948-1956. https://doi.org/10.1016/S0959 -8049(03)00427-1

31. Jung KK, Liu XW, Chirco R, Fridman R, Kim HR (2006) Identification of CD63 as a tissue inhibitor of metalloproteinase-1 interacting cell surface protein. EMBO J 25(17):3934-3942. https:// doi.org/10.1038/sj.emboj.7601281

32. Stetler-Stevenson WG (2008) Tissue inhibitors of metalloproteinases in cell signaling: metalloproteinase-independent biological activities. Sci Signaling 1(27):re6. https://doi.org/10.1126/scisi gnal.127re6

33. Liu XW, Bernardo MM, Fridman R, Kim HR (2003) Tissue inhibitor of metalloproteinase-1 protects human breast epithelial cells against intrinsic apoptotic cell death via the focal adhesion kinase/ phosphatidylinositol 3-kinase and MAPK signaling pathway. J Biol Chem 278(41):40364-40372. https://doi.org/10.1074/jbc. M302999200

34. Song G, Xu S, Zhang H, Wang Y, Xiao C, Jiang T, Wu L, Zhang T, Sun X, Zhong L, Zhou C, Wang Z, Peng Z, Chen J, Wang $\mathrm{X}$ (2016) TIMP1 is a prognostic marker for the progression and metastasis of colon cancer through FAK-PI3K/AKT and MAPK pathway. J Exp Clin Cancer Res 35(1):148. https://doi. org/10.1186/s13046-016-0427-7

35. Carpen T, Saarilahti K, Haglund C, Markkola A, Tarkkanen J, Hagstrom J, Mattila P, Makitie A (2018) Tumor volume as a prognostic marker in p16-positive and p16-negative oropharyngeal cancer patients treated with definitive intensity-modulated radiotherapy. Strahlenther Onkol 194(8):759-770. https://doi. org/10.1007/s00066-018-1309-z

36. Carpen T, Sjoblom A, Lundberg M, Haglund C, Markkola A, Syrjanen S, Tarkkanen J, Makitie A, Hagstrom J, Mattila P (2018) Presenting symptoms and clinical findings in HPV-positive and HPV-negative oropharyngeal cancer patients. Acta Otolaryngol 138(5):513-518. https://doi.org/10.1080/00016489.2017.1405279

37. Amin MB, Edge S, Greene F, Byrd DR, Brookland RK, Washington MK, Gershenwald JE, Compton CC, Hess KR, Sullivan DC, Jessup JM, Brierley JD, Gaspar LE, Schilsky RL, Balch CM, Winchester DP, Asare EA, Madera M, Gress DM, Meyer LR (2017) AJCC cancer staging manual, 8th edn. Springer, New York, $p$ 2017

38. Hanemaaijer R, Sorsa T, Konttinen YT, Ding Y, Sutinen M, Visser H, van Hinsbergh VWM, Helaakoski T, Kainulainen T, Rönkä H, Tschesche H, Salo T (1997) Matrix metalloproteinase-8 is expressed in rheumatoid synovial fibroblasts and endothelial cells: regulation by tumor necrosis factor- $\alpha$ and doxycycline. J Biol Chem 272(50):31504-31509

39. Tuomainen AM, Nyyssonen K, Laukkanen JA, Tervahartiala T, Tuomainen TP, Salonen JT, Sorsa T, Pussinen PJ (2007) Serum matrix metalloproteinase- 8 concentrations are associated with cardiovascular outcome in men. Arterioscler Thromb Vasc Biol 27(12):2722-2728. https://doi.org/10.1161/ATVBA HA.107.154831

40. Makinen LK, Hayry V, Atula T, Haglund C, Keski-Santti H, Leivo I, Makitie A, Passador-Santos F, Bockelman C, Salo T, Sorsa T, Hagstrom J (2012) Prognostic significance of matrix metalloproteinase- $2,-8,-9$, and -13 in oral tongue cancer. J Oral Pathol Med 41(5):394-399. https://doi.org/10.1111/j.1600-0714.2011.01110 .x

41. Maatta M, Tervahartiala T, Vesti E, Airaksinen J, Sorsa T (2006) Levels and activation of matrix metalloproteinases in aqueous humor are elevated in uveitis-related secondary glaucoma. J Glaucoma 15(3):229-237. https://doi.org/10.1097/01.ijg.0000212229 .57922 .72

42. Prikk K, Maisi P, Pirilä E, Reintam M-A, Salo T, Sorsa T, Sepper R (2002) Airway obstruction correlates with collagenase-2 (MMP-8) expression and activation in bronchial asthma. Lab 
Invest 82(11):1535-1545. https://doi.org/10.1097/01.Lab.00000 35023.53893.B6

43. Sorsa T, Mantyla P, Ronka H, Kallio P, Kallis GB, Lundqvist C, Kinane DF, Salo T, Golub LM, Teronen O, Tikanoja S (1999) Scientific basis of a matrix metalloproteinase- 8 specific chair-side test for monitoring periodontal and peri-implant health and disease. Ann N Y Acad Sci 878:130-140

44. Smeets SJ, Hesselink AT, Speel E-JM, Haesevoets A, Snijders PJF, Pawlita M, Meijer CJLM, Braakhuis BJM, Leemans CR, Brakenhoff RH (2007) A novel algorithm for reliable detection of human papillomavirus in paraffin embedded head and neck cancer specimen. Int J Cancer 121(11):2465-2472. https://doi. org/10.1002/ijc.22980

45. Prigge E-S, Arbyn M, von Knebel Doeberitz M, Reuschenbach M (2017) Diagnostic accuracy of p16INK4a immunohistochemistry in oropharyngeal squamous cell carcinomas: a systematic review and meta-analysis. Int J Cancer 140(5):1186-1198. https://doi. org/10.1002/ijc.30516

46. Gronhoj C, Jakobsen KK, Jensen DH, Rasmussen J, Andersen E, Friborg J, von Buchwald C (2018) Pattern of and survival following loco-regional and distant recurrence in patients with $\mathrm{HPV}+$ and HPV- oropharyngeal squamous cell carcinoma: a population-based study. Oral Oncol 83:127-133. https://doi. org/10.1016/j.oraloncology.2018.06.012

47. Serrels B, McGivern N, Canel M, Byron A, Johnson SC, McSorley HJ, Quinn N, Taggart D, Von Kreigsheim A, Anderton SM,
Serrels A, Frame MC (2017) IL-33 and ST2 mediate FAKdependent antitumor immune evasion through transcriptional networks. Sci Signal. https://doi.org/10.1126/scisignal.aan8355

48. McLean GW, Carragher NO, Avizienyte E, Evans J, Brunton VG, Frame MC (2005) The role of focal-adhesion kinase in cancer-a new therapeutic opportunity. Nat Rev Cancer 5:505. https://doi. org/10.1038/nrc1647

49. Klussmann JP, Mooren JJ, Lehnen M, Claessen SMH, Stenner M, Huebbers CU, Weissenborn SJ, Wedemeyer I, Preuss SF, Straetmans JMJAA, Manni JJ, Hopman AHN, Speel E-JM (2009) Genetic signatures of HPV-related and unrelated oropharyngeal carcinoma and their prognostic implications. Clin Cancer Res 15(5):1779-1786. https://doi.org/10.1158/1078-0432.ccr-08-1463

50. Hayes DN, Van Waes C, Seiwert TY (2015) Genetic landscape of human papillomavirus-associated head and neck cancer and comparison to tobacco-related tumors. J Clin Oncol 33(29):32273234. https://doi.org/10.1200/JCO.2015.62.1086

51. Lawrence MSea (2015) Comprehensive genomic characterization of head and neck squamous cell carcinomas. Nature 517(7536):576-582. https://doi.org/10.1038/nature14129

Publisher's Note Springer Nature remains neutral with regard to jurisdictional claims in published maps and institutional affiliations.

\section{Affiliations}

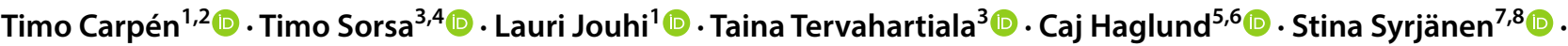

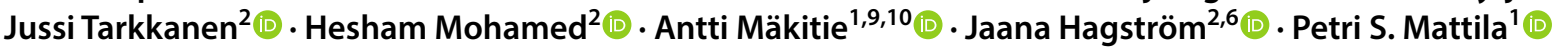

1 Department of Otorhinolaryngology-Head and Neck Surgery, University of Helsinki and HUS Helsinki University Hospital, P.O.Box 263, 00029 HUS Helsinki, Finland

2 Department of Pathology, University of Helsinki and HUS Helsinki University Hospital, P.O.Box 21, 00014 HUS Helsinki, Finland

3 Department of Oral and Maxillofacial Diseases, University of Helsinki and HUS Helsinki University Hospital, P.O.Box 41, 00014 HUS Helsinki, Finland

4 Department of Oral Diseases, Karolinska Institutet, Huddinge, Sweden

5 Department of Surgery, University of Helsinki and HUS Helsinki University Hospital, P.O.Box 440, 00029 HUS Helsinki, Finland
6 Research Programs Unit, Translational Cancer Biology, University of Helsinki, P.O.Box 63, 00014 Helsinki, Finland

7 Department of Oral Pathology and Oral Radiology, University of Turku, Lemminkäisenkatu 2, 20520 Turku, Finland

8 Department of Pathology, Turku University Hospital, Kiinamyllynkatu 10, 20520 Turku, Finland

9 Division of Ear, Nose and Throat Diseases, Department of Clinical Sciences, Intervention and Technology, Karolinska Institutet and Karolinska Hospital, 17176 Stockholm, Sweden

10 Research Program in Systems Oncology, Faculty of Medicine, University of Helsinki, Helsinki, Finland 